\title{
Ethics and Dialogue in Autobiography: The Cases of Vitomil Zupan and Lojze Kovačič
}

\author{
Andreas Leben
}

University of Graz

\begin{abstract}
Vitomil Zupan (1914-1987), a former partisan and political prisoner, and Lojze Kovačič (1928-2004) who was exiled as a German speaking child with his family from Switzerland to Yugoslavia, rank among the most outstanding autobiographers in modern Slovene literature. After a brief theoretical discussion on ethics and a dialogue on autobiographical discourse, the paper discusses the intersections and dialogical interplay between the real author, the writer, the narrator, the characters and the reader in their writings since the 1970s, taking into account the background of their personal experiences and the political, ideological and social conditions represented in their texts. As they pursued different concepts of self-representation, special emphasis is placed on ethical issues that derive from the autobiographical genre, respectively, from the specifics of the ethics of the told and the ethics of the telling as well as on the significance of ethical questions within the aesthetics of their writing.
\end{abstract}

\section{ABSTRACT IN SLOVENE}

Nekdanji partizan in politični zapornik Vitomil Zupan (1914-1987) in Lojze Kovačič (1928-2004), ki je bil kot nemško govoreči otrok pregnan s svojo družino iz Švice v Jugoslavijo, štejeta med najbolj prepoznavne avtobiografe v novejši slovenski književnosti. Po kratkem uvodu v narativno etiko in dialoškost $\mathrm{v}$ avtobiografskem diskurzu članek obravnava stičišča in razmerja med resničnim avtorjem, piscem, pripovedovalcem, protagonisti in bralcem z ozirom na osebne izkušnje obeh avtorjev ter na podobo političnih, ideoloških in družbenih razmer, ki so predstavljene v njunih besedilih od sedemdesetih let prejšnjega stoletja naprej. Ker se njuna koncepta samoreferenčnega pisanja 
med seboj razlikujeta, velja posebna pozornost etičnim vprašanjem, ki izvirajo iz značilnosti avtobiografskega žanra oziroma iz posebnosti glede etičnosti pripovedovanega in etičnosti pripovedovanja, ter pomenu etičnih vprašanj v sklopu Zupanove in Kovačičeve estetske prakse.

Keywords: Slovene autobiography, modernism, ethics, dialogue

\section{CONCEPTUALISATIONS OF ETHICS AND DIALOGUE IN THE} AUTOBIOGRAPHICAL DISCOURSE

To date in the theory of autobiography, ethical aspects have not been discussed very explicitly, even though the practices of self-representation as well as the discourses on autobiography in Western culture have always been concerned with ethical matters. John Paul Eakin's interdisciplinary collection The Ethics of Life Writing (2004) and especially his editorial preface is still one of the most cited references on this topic. Discussing the question of "what is the good of life writing, and how, exactly, it can do harm," Eakin stated that for the members of oppressed and silenced groups life writing has become a leading form of expression in postcolonial and minority literature. ${ }^{1}$ In his considerations on trust and betrayal, privacy and law as possible ethical limits of autobiography he stressed the problem that privacies are largely shared with other people and that it is "hard to demarcate the boundary where one life leaves off and another begins." ${ }^{2}$ He saw a potential ethical and practical resolution of the tensions posed by life writing in a certain "modus vivendi" between the right to free expression and the right to privacy. ${ }^{3}$ However, it was not Eakin's aim to give evidence about the broader dimension of ethics in life writing.

Going back to the consistent origins of the discourse on autobiography in the late $19^{\text {th }}$ and early $20^{\text {th }}$ century, to Wilhelm Dilthey and his disciple Georg Misch, ethical issues relate initially to the hermeneutic epistemological tradition. To this tradition and Dilthey's conception of the human sciences Mikhail M. Bakhtin also referred in his extensive article Author and Hero in Aesthetic Activity (Avtor i geroj v èstetičeskoj dejatel'nosti) ${ }^{4}$ from the early 1920s. ${ }^{5}$ According to Bakhtin, the position of outsideness (vnenakhodimost) is the necessity that the author must become another in relation to himself, that he "must be separated from the hero-from himself-totally, and one must define oneself purely in terms of values for the other, or, rather, in oneself one must come to see another," as the basic precondition for the author's aesthetic activity. ${ }^{6}$ Hence, the aesthetic event ends and an ethical event begins when the author and the hero coincide 
or when they find themselves standing next to each other in the face of a value they share, or as antagonists, like in tracts, manifestos, speeches of accusation or of praise and gratitude, invectives and confessions. ${ }^{7}$

Moreover, detecting a crisis of authorship, Bakhtin assumed that the position of outsideness, which enables the author to assemble and consummate all of the cognitive-ethical determinations and valuations of the hero into a unitary and unique whole, might begin to incline toward the ethical position of the hero, and thus to moral, social, political and practical-life outsideness. In this case, the position of outsideness becomes "excruciatingly" ethical because "the insulted and injured" become heroes for the act of seeing which is no longer purely artistic; accordingly, life transforms "into a tragedy without a chorus and without an author." Here, specific answerability can be founded only upon trust that there is another-the highest other, and trust in the fact "that I do not act in an axiological void. Outside this trust, only empty pretensions are possible." ${ }^{9}$

In Bakhtin's considerations the ethics relate first of all to the "open ethical event ... of lived life," respectively, to the "unitary and unique event of being." 10 They are part of his broader concept of answerability that is based on the idea of balance between the need of normative authority that is represented by the other, and the principle of infinite openness of self-other relations. ${ }^{11}$ However, his considerations on ethics and his later elaborated conceptions of dialogism and polyphony in language are linked with contemporary concepts of polyvocality or polyphony in autobiographical narrations. ${ }^{12}$ They also have convergences with Hannah Arendt's notions on human activity and plurality in The human condition (1958) as well as with the anthropological reflections on ethics and morality that Paul Ricoeur developed in his narrative theory and, specifically, in the monograph Oneself as Another (Soi-même comme un autre, 1990) where he basically distinguished four different levels that make up hermeneutic and ethical perspectives: language (the speaking person); action (the acting/suffering person); narration (the narrating person); and ethical life (the responsible person)..$^{13}$ With recourse to Aristotle and giving axiological primacy to the ethics over morality, Ricoeur characterised ethics as the orientation towards a "good life" and the final aim of human activity whereas morality-despite its dialogical structure-is discussed with reference to universal norms, laws and rules that are again dialogically related to the ethics of a person's self. ${ }^{14}$

However, the research interests in this field frequently relate to topics such as the Shoah, trauma, terror, violation, human rights, law, resistance and feminism, touching upon questions of freedom, politics and democracy. ${ }^{15}$ Thus, the discourse on ethics often refers to historical matters, to the nexus between the individual and the society, the intimate and 
the public sphere, focusing on mutual and dialogical aspects in the relationships between the self and the other(s), the author and the reader(s). Sidonie Smith and Julia Watson elaborated with respect to ethics in writing life narratives a catalogue of questions, that is basically related to two aspects: first, to a kind of ethics of authorship, asking for instance what details a writer divulges or avoids about his life and other people with respect to cultural conventions at the historical moment of writing, and second, to the "ethics of readership" which refers to ethical concerns of the reader in reading such writings and to his assessment of the narrator. ${ }^{16}$

A systematisation of the topic of ethics in literature is provided by James Phelan in a synoptic presentation of approaches in narrative ethics that is also instructive with respect to life narratives. Phelan notes that investigations into narrative ethics focus on one or more of the following four issues: (1) the ethics of the told; (2) the ethics of the telling; (3) the ethics of writing/producing; and (4) the ethics of reading/reception. ${ }^{17}$ The ethics of the told focus on characters and events; the ethics of the telling focus on text-internal matters involving implied authors, narrators and audiences; the ethics of writing/producing focus on text-external matters involving actual authors, film directors or other constructing agents; finally, the ethics of reading/reception focus on issues about audiences and the consequences of their engagement with narratives.

With concern to ethics and dialogue in the autobiographical writings of Vitomil Zupan and Lojze Kovačič that will be discussed here, the ethics of the told and the ethics of the telling are of most relevance, also including the ethics of writing as a part of the telling and taking into account as well as metatextual and other transtextual aspects, as both authors refer to the process of writing itself. What makes Zupan and Kovačič particularly significant with respect to discourse on ethics in autobiography is the fact that they wrote about themselves in a highly self-reflected way over a long period, also touching on numerous aspects of historically taboo subjects in literature such as sexuality. Due to the fact that they pursued different concepts of autobiographical self-representation, it is necessary to outline some characteristics of their work and writing practices.

\section{ZUPAN'S AND KOVAČIČ'S CONCEPTS OF AUTOBIOGRAPHICAL WRITING}

Before and even during World War II Vitomil Zupan (1914-1987) wrote a number of novels. Most of them had no explicit autobiographical character and were published only in the 1970s along with his new texts like Levitan. A Novel or Maybe Not (Levitan. Roman, ali pa tudi ne, 1982, written 
in 1970), Minuet for Guitar - in Twenty-five Shots (Menuet za kitaro - na petindvajset strelov, 1975), The Game with the Devil's Tail (Igra s hudičevim repom, 1978), The Comedy of Human Tissue (Komedija človeškega tkiva I-II, 1980) and the posthumous Apocalypse of Triviality (Apokalipsa vsakdanjosti, 1988) which form a kind of autobiographical pentalogy. It is well known that Zupan, at least since the 1960s, shared Henry Miller's belief in the need of "writing life, not literature." 18 With reference to writers who refused descriptive literature as a possibility of the experience of man and the world, Zupan was convinced that the time of storytelling in all arts has passed since man in the face of the announcements of catastrophes and cataclysms woke up from optimistic dreams and progressive visions. ${ }^{19}$

Even though Zupan referred in the texts mentioned above to personal experiences and to his own life, the narrator or the protagonist is never to be identified with the real author, even if the biographies coincide or the narrator/writer seem to share the author's values and world view. In the unpublished preface to Levitan, a first person narrative about the pain of the unfulfilled sexual desires of prisoners as an unjust punishment within the penal institution, the writer (pisec) explains that the text is not a memory book but an amalgam of different experiences and related stories. Thus, the narrator's name is Levitan who is an invented figure composed of several individuals, as well as "the beings in the stories" who are composed of "factual components" into an invented whole. ${ }^{20}$

In The Game with the Devils Tail (1978), a third person novel about the sadomasochistic relationship of a couple in the course of divorce, there are no explicit autobiographical references at all. But even in Zupan's first-person narratives the autobiographical elements and personal experiences are consequently fictionalised or mingle with fiction. On the level of personal names there never is an identity of the author, the narrator and the main character in the sense of an autobiographical contract. In the war novel Minuet for Guitar (1975) the relationship between the nonnamed author, the narrator and the "hero" is even more muddled, as the writer in the preface declares to have "copied" the diary notes of the partisan Jakob Bergant-Berk by adding some of his own experiences into a "connective" (zveznost). ${ }^{21}$ In fact Zupan had already written parts of the story during World War II. ${ }^{22}$

Zupan's most autobiographical text, The Comedy of Human's Tissue I-II (1980), is an extensive essay where the unnamed narrator/writer describes his life and intellectual formation from childhood until after the war. Right from the beginning he refers to the process of writing and distinguishes between different 'I-s' he detects in himself, such as the "writing I", the "sportive I", the "woman-loving I", the "soldier's I", the "captivity I", the "creator I", "the God I", etc. ${ }^{23}$ At a certain point the narrator finds 
that his writing is a matter of pure construction: "I am a story that tries to tell a story, and suddenly realizes that there are no stories at all. I am the posthumous voice of a night that maybe never existed." ${ }^{24}$

However, in most of Zupan's autobiographical writings the narrator is engaged in reflections about society, culture and human existence, giving at the same time insight into the life of the real author from childhood until old age and the forming of his personality. It should also be noted that Zupan is considered to be the only Slovene novelist who dealt with eroticism as a theme in all of his works and even created the great narratives from an erotic perspective. ${ }^{25}$ This is also true for his last book, the unfinished Apocalypse of Triviality (1988) where the narrator in the face of old age, illness and death turns to ironic or cynical fatalism and a pessimistic view on the future of society and humanity.

In contrast to Zupan, Lojze Kovačič (1928-2004) was an explicit autobiographer who since 1945 wrote about his individual experiences and in the early 1960s definitively decided not to write about others but only about himself. ${ }^{26}$ Starting with the prose collection The Town Keys (Ključi mesta, 1964) and the novel The Boy and Death (Deček in smrt, 1968) Kovačič gave evidence about occurrences, experiences and imaginations relating to his life, even before his birth, until old age and his anticipated death in more than 10 books including the essay Workshop: The School of Writing (Delavnica: Šola pisanja, 1974), Five Fragments (Pet fragmentov, 1981), the trilogy The Newcomers (Prišleki I-III, 1984/85), the collection of fragmentary notes Dust (Prah, 1988), Basel (1989), Crystal Time (Kristalni čas, 1990), The Descent (Vzemljohod, 1993), Things of Childhood (Otroške stvari, 2003) and the posthumous Maturity Matters (Zrele reči, 2009). Like Zupan he was concerned with the fundamental questions of human existence: Who we are? Where do we go? In trying to find an answer, he wrote about himself and his relationship to others in different periods of his life giving insights into his perception and reflections on life, society, literature and his way of writing as well. His intention was to find out from a highly solipsistic perspective as much as possible about himself as a representative of the human species by observing and describing himself in the totality of his existence. Whereas Zupan in his considerations on human existence derived from a universal point of view and referred to philosophy, history and other human sciences, Kovačič advanced to universality by going inside himself, as the life of an individual, at a certain point, becomes universal.

Hence, intimism was significant for many of Kovačič's texts since the early 1970s, when he wrote the book Five Fragments (1981) of which the part about the relationship to his first wife and other women was republished with the title Three Loves (Tri ljubezni, 2004). The books Crystal 
Time (1990), The Descent (1993), Things of Childhood (2003) and Maturity Matters (2009) have their origin in the handwritten notes Kovačič wrote since the end of the 1980s in ordinary school exercise books. ${ }^{27}$ In all of them, except Things of Childhood, the present and the past mingle. The distinctions between the narrated I and the narrating I can totally merge because the focus is now on the physical, mental and cerebral life of a writer who in old age observes himself, reflecting on his current and former life and his relationship to the people and the world that surround him in the face of approaching death.

Already in the essay Workshop: School of Writing (1974) Kovačič mentioned that he has started to write in a new way that is similar to an intimate diary ${ }^{28}$ Life here is discussed as a chaotic, ongoing and inconsummate process, but not in the sense of Bakhtin's "unitary and unique event of being" ${ }^{29}$, as Kovačič emphasised that the only face a modern creator can honestly wear is the fragment as an "expression of a world which does not close itself or which cannot close itself anymore." Accordingly, he expects from such literature that "nothing shall be bound anywhere, neither spiritually, nor finally: as unconvincing as life, open, an antithesis to everything, the chaos through which the human being walks in his cerebral, rather than in his sexual or inherited sphere." ${ }^{30}$

Regarding the question of literary (self) representation Kovačič paid close attention to the relations and gaps between personal experience, language and reality. As life itself is chaos, a process of open-ended becoming, and he is for himself consciously accessible only up to $3 \%$ or even $0.3 \%$ whereas the rest remains a "black zone" that is inhabited by millions and billions of relatives and ancestors, ${ }^{31}$ all his attempts to understand himself in the end must fail. Thus, with respect to his self-portraits from different life periods, he finally cannot say: "that is really me." ${ }^{32}$

As is evident, Kovačič did not really believe that writing an autobiography is indeed possible. Ironically he even found that God is the greatest of all autobiographers as he has created the human being in his image, and that the rumours about autobiography are failed and kitschy. ${ }^{33}$ Accordingly, it is not surprising that neither Kovačič nor Zupan decided to write classical autobiographies but created hybrid self-representations by combining (fictionalised) autobiographical narratives with metareflective essays. What they did was to write a small number of short curricula vitae, two of which are briefly summarised below to give an insight into what the authors themselves stressed in their biographies. Zupan's CV dates back to 1979 and is written in the third person, perhaps for a foreign publisher. ${ }^{34}$ Kovačič's CV is written in the first person and was published in $1987 .{ }^{35}$ The CVs are supplemented with some data in the square brackets. 


\section{TWO CURRICULA VITAE}

Vitomil Zupan: Born on the $18^{\text {th }}$ January 1914 in Ljubljana, Slovenia, son of Slovene parents, his father, who was an officer in the Austro-Hungarian Army, died in 1916 in Bessarabia. He began to write before he attended school, sewing his stories together into little books. He saw them for the last time in 1948 on the table of a police interrogator. In 1933 his first short story was published. He graduated in 1959 as a construction engineer. Until then he had about 17 different jobs as a sailor, ship's stoker and house painter in France, professional boxer and ski instructor. He travelled a lot, learned languages, and had a sort of aversion to printing his writings. Voluminous texts emerged which were printed up to 30 years later, together with the recent texts. All in all he has published about 30 books. He wrote several texts for the theatre, radio and TV, scenarios for five or six films, and got several public and national awards.

Before WW II he was a member of a left-wing student opposition movement and was arrested several times. Coming back from France, he supported the Slovenian liberation movement. When he returned from an Italian concentration camp he joined up with the partisans where he wrote some one act plays, short novels and an award winning drama. After the war he disagreed with the theory of Socialist Realism. In 1948 he was arrested, and after a show trial without evidence or witnesses, was found guilty of amorality, trial violence (without naming the victim), attempted murder, provoking a woman's suicide, hostile propaganda (satirical verses, cartoons), spying and unpatriotic activity. He was sentenced to 15, then to 18 years of imprisonment. He fell sick with tuberculosis and was the first Yugoslav prisoner who had a lung operation. He was released after 7 years in jail.

A year later he received an award for a novel that was published more than 10 years after it had originally been written. He worked on film productions and published for several years under different pen names. Some of his texts disappeared, some (mostly anonymous) received awards. The style of his prose is very different, with a third-person or first-person narrator. There followed times of intensive studies (biology, physics, chemistry, medicine and foremost: psychology) and times of literary experiments. He had his breakthrough with the novel Minuet for Guitar-in 25 Shots.

The texts he wrote in prison for the most part have not been published (poetry, essays, juvenile literature, drama). For 5 or 6 years it was strictly prohibited for him to use pencil or paper, thus, they were written in secret and had to be smuggled out of the prison. Some of his experience in prison he described in the novel Levitan (a novel or maybe not) which could not appear in his native country [until 1982; also, with the exception of 
his essays, most of the texts from his imprisonment were later published]. Nevertheless, a number of old and new novels appeared in Ljubljana and Beograd.

In the system the label of being a former political prisoner is indelible; the problems and successes of the author are therefore in high imbalance. He has to take note of the advantages and disadvantages, as if he does not know the background. Awards and shame follow each other closely. The author was twice married and twice divorced. He has three children. [Zupan died in 1987 in Ljubljana and was buried, as was his wish, in a partisan uniform.]

Lojze Kovačič: In 1899, his father set out from a small village in Slovenia to learn the craft of tailoring and married, in 1908, a German dressmaker-against her will. After living in Bruxelles, France, Trieste, Vienna and Prussia, they settled down in Basel in 1912 where Kovačič was born in 1928 as their third child. During the world economic crisis the family was impoverished. At the age of five he fell sick with pneumonia and tuberculosis. Because his father did not have Swiss citizenship the family was exiled in 1938 to Yugoslavia where they were regarded as "hated Germans." He did not understand the language of his father and perceived the fact that there was only one language in use as linguistic impoverishment. From 1939 he lived in poverty with his parents, his sister Claire and her daughter Gisela in the village where his father was born, in Ljubljana.

He restarted school at elementary level and failed the second year. In 1942 his parents opted for "repatriation" to the German Reich, but retracted their decision in the same year. In 1944 his father died (the theme of the book The Boy and the Death and the trilogy The Newcomers). In April 1945 his first text was published. In December his mother, Claire and Gisela were displaced to a refugee camp in Austrian Carinthia. Kovačič decided to stay and was prosecuted for selling national property-his father's sewing machine. He was set free after 3 months, had to leave his home and wrote autobiographical texts for different magazines for young people.

In 1947 he lost his scholarship because of his average success in school and behaviour that was both ethically and morally suspicious. For several months he had no place to stay and he lost his job at a magazine because he invited the daughter of a Belogardist to an editorial conference. In the Yugoslav army he was sentenced to 6 months in a disciplinary battalion where he had to clean grenades, mines and aircraft bombs. In 1950 he came back to Ljubljana. He married in 1951 and had two children. In 1957 he was sent for trial as a result of the publication of an extract of his novel The Golden Lieutenant [about his experiences in the Yugoslav army]. Until 1959 he had no regular job. He enrolled at the Pedagogical 
Academy (German and Slovene) and graduated in 1963. He lived from proofreading work and from scripts that he wrote for a puppet theatre on television. Finally he got a job as a dramatic advisor at a puppet theatre, then as a teacher in the didactics of puppetry and as a mentor for literary education. [Since the end of the 1960s Kovačič has received a number of literary awards; in 1997 he was elected as an associate member of the Slovenian Academy of Science and Arts. He died in 2004 on the day Slovenia joined the European Union].

\section{BETWEEN ETHICS, DIALOGUE AND DIALOGICAL ETHICS}

When we compare the CVs it is significant that Kovačič pointed out the story of his family, whereas Zupan focused on his writings as a former political prisoner. The texts also refer to their experiences of social and ideological exclusion as both came into conflict with political powers in the pre-, mid- and post-war periods. With reference to their different concepts of self-representation, the question arises as to how they dealt in their writings with this and other social experiences in terms of ethics and how they represented interpersonal relationships. Here, a special emphasis is placed on the intersections and dialogical interplay between the real author, the implied writer, the narrator, the characters and the implied reader and the ideological, political, and social background as it appears in the texts. Thus, as mentioned above, the focus is on the ethics of the told and the telling. With respect to the responsibility of the author/writer-who at the same time figures as the narrator-for the totality of the text this nexus could be dubbed as the ethics of authorship.

Kovačičs explicit autobiographical, autodiegetic narrating I and narrated I as well as the implicit alter ego in the texts of Zupan are orientated towards a "good life" only up to a certain extent, as they are interested more in the truth of human existence than in ethical acting. In Zupan's works, particularly Levitan, common moral conventions are discussed and consequently exceeded. ${ }^{36}$ Nevertheless, it can be seen as an ethical decision that Zupan, who fictionalised autobiographical elements without hiding them, normally did not use any real names, his own or his relatives, friends or other people he was involved with. Very differently, in Kovačič's writings various forms of representation of personal identity and interpersonal relationships can be detected. His close family members are always called by their real name or authentic nick-names, whereas the narrating I or the narrated I normally is nameless, except when the narrator refers to himself as a child and uses the German nickname "Bubi" (little boy) as in The Newcomers. When the narrator refers 
to his first and second wife or other women, describing intimate sexual details, he mostly uses initial letters as in Five Fragments (e.g. C, D, M, S) and Crystal Time (B, C, D, O, V). Only in Maturity Matters the names of his three loves-Vida, his first wife, and his lovers Andreja and Darja-are disclosed $^{37}$ and he talks freely about the harmonic relationship with his second wife Beba and her daughter Tina. Other real persons are represented by initial letters, the name, or with decipherable pseudonyms as in The Newcomers. ${ }^{38}$ Thus, Kovačič initially concealed the identity of certain persons whereas he had no such concerns regarding his family members, as his father died in 1944, his mother in 1951, and his siblings lived outside Slovenia. However, it is remarkable that Kovačič hardly ever mentions his own children or the children of his partners, as if he did not want to involve the following generation in his writings.

As the narrating I and the narrated I in Zupan's and Kovačič's texts figure as social, political, practical-life and moral outsiders in Bakhtin's sense, they may fail in their ambitions for "a better life" due to social circumstances or themselves alone. In Zupan's autobiographical writings the gap between the vitalistic "I" and society is practically insurmountable. Moreover, the represented relationships between man and woman are mostly inconsistent or problematic and are frequently characterised by different forms of sadomasochism. The narrator as a young man does not believe in the possibility of equality in sexual relationships, as there is always someone who occupies and someone who is occupied and the winner is always the one who is "more spoiled." Sexuality means violence, power, struggle, lust and torture, and its "ethical" goal is to get rid of the cultural chains in order to achieve by total defacement a "primary state." ${ }^{39}$ However, with regard to intimacy the narrator nevertheless maintained certain principles as the sexual acts are not described in detail. The reason for this the narrator explains in The Apocalypse of Triviality where he calls himself "a piece of philosopher mixed with an erotomaniac": he is not willing to serve in any sense the politicians or the "middle class onanists" (meščanski onanisti) who had exploited the writers for thousands of years. ${ }^{40}$

Because Kovačič expected from his writings that everything has to be told, his depictions of sexuality are more explicit than those of Zupan. In Five Fragments and The Newcomers they can extend up to several pages and are described strictly from the perspective of the sexually aroused protagonist and his awareness of his surroundings. In some sequences the figures even transform into pure sexual heroes as the narrative is focused on the sexually stimulated body and mind when all objects and substances receive a sexual impact. Nevertheless, sexuality in Kovačič's writings is not bound only by the biological, physical or psychological sphere but first of all relates to the unsettled and inexperienced young 
protagonist, his desire for love, emotional security, and, with concern to the circumstances of the post-war period, even to social security. The narrated I also tries to anticipate what the woman he sleeps with expects from him. Thus, sexuality is not an end in itself and women are not an object of pure sexual desire but turn out as absolutely superior to men. They are "the number one in nature," creative for themselves and the mothers "of mankind and humanity." ${ }^{11}$ The narrator finds emotional tranquility and new responsibility in his second marriage but with regard to his first wife who committed suicide he feels irreducible guilt that lies in the past. ${ }^{42}$ He condemns himself for not finding love in the marriage, meaning a "love without illusions." In a monologue at her grave which he regularly visits, he tries to explain their conflictive relationship as being the result of the "aggressive" morality, in which she believed, whereas for him his understanding of morality was the only protective shield he had in his love-hate for her. ${ }^{43}$

The narrator/writer in Kovačič's text gives evidence that he is aware of the ethical dilemmas that arise from his writings as they are based on "real" life and "real" people: "How naughty, insolent, ugly you must be when you settle in the texts existing people, these half dead beings. How many bad things you write down in the end about people you love (and how often do you think or tell about them without remembering that you are unfair). But you cannot withdraw the words not even in the moment when you regret them the most." He considers his inability to write fictional literature. ${ }^{44}$ Thus, he explains and justifies his indiscretions by the writing style, elevating aesthetical considerations above ethical reservations.

In Zupan's texts the narrator/writer does not discuss ethical questions of personal guilt but he gives himself the aura of a humanist. He stylises himself as the "CREATOR I" (STVARNIK-JAZ) that in contrast to his other I-s does not know any morality like God himself. ${ }^{45}$ Nevertheless, he is the bearer of certain basic ethical principles and criticises the self-destroying tendencies and the murderous and mass killing history of mankind, such as the English concentration camps in South Africa, the genocide of the Armenians, the Nazi extermination camps, Stalin's gulags, and "the shame" of his own country: the political prisons and camps, the methods of reeducation and the "genocide" of political and ideological opponents. ${ }^{46}$ At the same time, in old age and in the face of death, the narrator's will to power and the disposition of the right of the strongest, interchange with self-irony, melancholy and cynicism. The narrator becomes more and more misanthropic and indifferent to human civilisation, giving himself the following answer to the question of where we go and who we truly are: "Basically there is digestion and ignorance."47 
However, with respect to Zupan's seeing of the human existence as a game of power and contingency without metaphysical sense it is not surprising that he did not discuss either the fact that he accidentally shot a friend at the age of 18 or that he was involved in the suicide of a young woman shortly after the war but only reports that these incidents happened. As Janko Kos has already stated, in Zupan's novels guilt is not guilt and punishment is not punishment, as in his texts there is no real internal development, no aim, and the course of events can be continued endlessly. ${ }^{48}$

The narrators in Zupan's and Kovačič's writings are, as noted above, individualised outsiders who correlate in many aspects of their respective biographies. It is worth pointing out that neither of them styled himself as a dissident and did not explicitly polemicise against the political order, even though they were in serious conflicts with the authorities-Zupan because of his nonconformism, Kovačič because of his German background. The latter has even been admitted into the Communist Party as a candidate. What also made both of them "suspicious" in the post-war period was the fact that their writings did not fit well with the collectivistic aesthetics of Socialist Realism. Moreover, with respect to their biographies and personal experiences, their literature immanently mirrored unpleasant aspects of that time and touched upon officially concealed or socially marginalised taboo subjects. Zupan, for instance, who documented in Levitan his struggle to survive in prison by illegal writing and his strategies on how to suppress, transform and contemplate sexuality by imagination and reading literature and philosophy, became an advocate for the (political) prisoners. Levitan even mentions the infamous prison island Goli Otok. The Serbo-Croatian translation was one of the cult books of the Yugoslav punk and new wave generation, because it was read as a courageous rebellion against the system and the communist party. ${ }^{49}$

Unlike with Zupan the narrator in Kovačič's texts does not refer to the social, political and historical circumstances as such but represents them only as far as they relate to his or his alter ego's consciousness. This internal focalisation is clearly evident in the The Newcomers where the narrator describes the life and experiences of the boy he used to be, after his family was expelled from Switzerland until the post-war period in Ljubljana. Because the boy and his family were unwelcome strangers who tried to survive on the social margins, the trilogy naturally refers to occurrences and events that were in the post-revolutionary socialist society considered taboo. Thus, the Italian occupation from the boy's perspective seems to have its most dramatic effect in changing the sexual life in Ljubljana; his sister falls in love with a good natured German soldier; towards the end of the war the protagonist sympathises with the "Whites" and with the 
people who had to flee from Ljubljana; when the partisans march in and the people celebrate, the Kovačičs are terrified of being arrested. Other events that are mentioned include the repression of political and ideological opponents, the execution of thousands of members of the Nazi-allied forces after the war and the so called Dachau Trials against survivors of German concentration camps, who were accused of collaboration with the Nazi regime.

The detailed chronicle is not a counter history to the official one, but rather presents another side of history by showing the life of a family on the social margins that is exposed to the impacts of ideologies, politics and war. Nevertheless, the story lacks any ideologically contaminated messages and does not relate to values of right and wrong or good and bad. As a consequence of Kovačičs maxim that everything has to be told, the act of autobiographical writing itself appears as an ethical activity as it produces visions of existential truth. Literature was for Kovačič one of the "rare reservations of human freedom" ${ }^{50}$ and-as his self-referential commentaries indicate-an existential, aesthetical and ethical answer to his real life, a possibility to escape from reality, and, potentially even a "hidden suicide." 51

Kovačič's and Zupan's narrators share the position of "ethical outsideness" but deal very differently in terms of ethics which is also the result of different conception of the telling. In line with it there are also significant differences regarding the dialogical relationship between the author, the narrator, the characters and the reader. In Zupan's writings the "creator I" may overlap and control the other I-s but the position of a normative transgredient ethical authority is lacking as the narrator and the writer seem to be unified in the same ontological seeing of man and the world. In the relevant texts the author's intention to engage in dialogue with the reader is significant and rather conventional, as he is directly addressed by the implied author or narrator/writer in the prefaces, the introducing chapters or in the texts themselves but there is no real dialogue. The reader is the one who has to be instructed about the nature of presented text and in a way educated or he is addressed as a representative of the inferior mediocrity, the bearer of conventional morality and double standards. In the unpublished preface of Levitan the author notes that the book has not been written to entertain the readers but to give advice to those who tolerate prisons of the old type, and he is aware that the book will be read by "dirty slobs" as well. ${ }^{52}$ In The Game with the Devil's Tail the narrator/writer dedicates his writings "to the most stupid people of the world" who slipped on the vulgar like he himself did. ${ }^{53}$ But there are other aspects of dialogicity in these texts such as the intertextual dialogue with numerous other authors Zupan quotes or refers to. Not least, 
his writings have a polyphonic structure with regard to language and cultural hierarchies: philosophy mingles with the banalities of everyday life and standard Slovene is mixed up with sociolects, vulgarisms, and other languages like German, English, French, Spanish, Latin, and even Romani. This hybridisation and the merging of the high and the low can be seen as an ethical statement on the equality of all aspects of human culture.

Kovačič also used German in the dialogues of The Newcomers and in other texts or Serbo-Croatian with reference to his military service, but he did so to emphasise the authenticity of the told. In his writings it is hardly possible to find a direct dialogue with the reader. Nevertheless, the implied reader is always present and the narrator's voice itself is also conceptualised dialogically. There is, for instance, the implicit dialogue of the author with himself, the dialogue with the represented characters and the implicit polyvocality or polyphony within the telling and within language as such. Kovačič, in his essay Workshop: School of Writing, begins in a manner similar to a diary, giving evidence that he considered himself to be the first addressee of his texts, assuming that telling oneself and not others was the main achievement one could realise: there is "nothing more fruitful for the reader than attending as third witness the consistent dialogue of the author with himself." ${ }^{\prime 4}$ This disposition enables him to reflect on himself and his writing activity in a transtextual way as well as on his relationship to others. These others are at the same time immanent to this self-dialogue and an integral part of the represented self, because in Kovačič's understanding of himself and human existence all the people he knew as well as all their unknown ancestors have left invisible traces on both language and culture. In Kovačič's words: "Nobody who is the other is completely another but is me, the same way that I ... have never been completely different from the others." ${ }^{55}$ Thus, the "other" does not appear as an authoritative ethical principle; he is on the same level as the I, equal to him or overlapping with him and is filtered through the writer's consciousness in the dialogue of the author with himself.

Finally, there are in Kovačič's writings specific forms of an intertextual dialogue. There is, of course, the dialogical relationship with his own texts, forming a kind of fragmentary autobiography where certain periods are described and revisited several times and from different angles. On the other side there is a dialogical relationship to other authors, to literature, and, basically, to everything verbal that passed through his mind. Summing up his writings he was not even sure if the stories he wrote were indeed the "subject matter" of his life, as he wrote them according to all what he has read in other books and that he has heard from other people. Thus, he saw in his books a kind of "collective text" that was dedicated to 
the readers. ${ }^{56}$ Sometimes he even had the feeling that in the end nothing belonged to him as if everything was stolen, lent and pulled out of the situation. ${ }^{57}$ In line with this, he considered literature to be the handicraft of a copyist, like the apostles who copied full pages from the Bible.$^{58}$ However, Kovačič was convinced that he used certain parts with more legitimacy than the original author did. He justified this ethically ambivalent practice for a writer with the argument that for the functioning "organism" of a book man is prepared to not only steal but also to betray and to kill, not only oneself but also others, the nearest fellows. ${ }^{59}$ This, once more, indicates that in the end, in Kovačič's autobiographical writings, aesthetical values are above all ethical considerations.

\section{CONCLUSIONS}

The biographies of Vitomil Zupan and Lojze Kovačič are characterised by the personal experiences of the periods before, during, and after World War II. Both of them figured, for different reasons, as social and literary outsiders, although they were widely read and successful authors. As their biographies touch on many issues that were suppressed or taboos in the socialist society, their decision to write about themselves is not only of conceptual and aesthetical relevance but it also has an eminent ethical dimension of its own. Zupan's Levitan, for instance, was written and received as a voice of the insulted and injured, whereas Kovačič's The Newcomers represented the oppressed and silenced groups that were socially excluded or marginalised after the war because of ethnic, linguistic and ideological reasons. Both of them referred in their writings to morality but rejected it as a normative value for the act of writing as well as a category of literature. Moreover, the humanistic disposition of Zupan's narrator contradicts his or his alter ego's activities and the seeing of a world that has neither a deeper existential nor a metaphysical sense, but is based on contingency, instinct, and biology. In the same way, in Kovačič's writings morality is not a matter either of the narrator/writer's descriptions of his life that is seen as a fragmented, impenetrable and consciously incomprehensible process or of his reflections on himself as an individual that is developing and vanishing within the universal continuum.

With regard to the ethics of the told, the telling and the writing one main difference between them is that on one side Kovačič wrote explicitly autobiographically from the very beginnings whereas Zupan fictionalised his self-referential writings. Thus, for Zupan it was easy to conceal, if necessary, the identity of real persons and the references to true events or personal intimate details. With the intent to tell everything about himself, Kovačič for the most part wrote freely about all aspects of his existence 
as well as about his family, friends and lovers who can normally be identified even when he used initials and pseudonyms, limiting himself only in regard to his own children or the children of his partners. Unlike Zupan, he referred to questions of personal guilt and ethical dilemmas that arise from his writings, but when in doubt he gave priority to the needs of the aesthetics of telling.

Another difference that is significant with respect to the interplay between author, writer, narrator, characters and reader is Kovačič's subtle concept of dialogicity. Whereas in Zupan's writings the narrator/writer intends to engage in an explicit dialogue with the reader and the world as well as with other authors, Kovačič is not only in a long-term dialogue with himself and with people that were important to him but also the writings which he dedicated to the readers, appear as dialogical and polyvocal within themselves as this dialogue is based on hidden or unconsciously embedded intertextual and polyphonic relations, as he described in his metatextual reflections. In line with this and his understanding of the universal connectivity of human culture and everything existing, the selfother relations in Kovačičs writings are highly dialogic and of infinite openness even though they are represented from a solipsistic point of view.

\section{WORKS CITED}

Bakhtin, Mikhail M. "Art and answerability." Eds. Michael Holquist and Vadim Liapunov. Art and answerability. Early philosophical essays of M. M. Bakhtin. Trans. Vadim Liapunov. Austin: University of Texas Press, 1990. 1-3.

Berger, Aleš ed. Vitomil Zupan. Ljubljana: Nova revija, 1993.

Dolgan, Marjan. "Véliki tekst o demistifikaciji 'Velikega teksta' ali Prišleki Lojzeta Kovačiča." Ed. Marjan Dolgan. Slovenska književnost tako ali drugače. Ljubljana: Slovenska matica, 2004. 141-165.

Eakin, Paul John. "Introduction: Mapping the ethics of live writing." Ed. Paul John Eakin. The Ethics of Life Writing. Ithaca, London: Cornell University Press, 2004. 1-16.

Jergović, Miljenko. "Čebele in ljudje." Ed. Ifigenija Simonović. Vitomil Zupan. Važno je priti na grič. Življenje in delo Vitomila Zupana (1914-1987). Ljubljana: Mladinska knjiga, 2014. 363-366.

Kos, Janko. "Zločin in kazen Vitomila Zupana." Ed. Aleš Berger. Vitomil Zupan. Ljubljana: Nova revija, 1993.

Kovačič, Lojze. Sporočila iz sna in budnosti. Opuskule. Ljubljana: Mladinska knjiga, 1987.

Kovačič, Lojze. Prah. Dneunik, zapažanja, reminiscence. Ljubljana: Mladinska knjiga, 1988.

Kovačič, Lojze. Kristalni čas. Ljubljana: DZS, 1990.

Kovačič, Lojze. Vzemljohod. Ljubljana: Slovenska matica, 1993.

Kovačič, Lojze. Delavnica. Šola pisanja. Maribor: Založba Obzorja, 1997.

Kovačič, Lojze. Tri ljubezni. Ljubljana: Sanje, 2004.

Kovačič, Lojze. Zrele reči. Ljubljana: Študentska založba, 2009.

Leben, Andrej. "O »Zrelih rečeh« in drugih stvareh Lojzeta Kovačič." Ed. Alojzija Zupan Sosič. Sodobna slovenska književnost (1980-2010). Ljubljana: Znanstvena založba Filozofske fakultete, 2010. 157-163. 
Leben, Andreas. "From Bakhtin to Kovačič: From the Ethics to the Aesthetics of Life in Autobiographical Writing." Slovene Studies 36.2 (2014): 83-95.

Nielsen, Greg Mark. The Norms of Answerability. Social Theory Between Bakhtin and Habermas. Albany: State University of New York Press, 2002.

Phelan, James. "Narrative ethics." http://www.lhn.uni-hamburg.de/article/narrative-ethics. Pibernik, France. Čas romana. Pogovori s slovenskimi pisatelji. Ljubljana: Cankarjeva založba, 1983.

Ricoeur, Paul. Das Selbst als ein Anderer. Translated by Jean Greisch in cooperation with Thomas Bedorf and Birgit Schaaff. München: Fink, 1996.

Simonović, Ifigenija ed. Vitomil Zupan. Važno je priti na grič. Življenje in delo Vitomila Zupana (1914-1987). Ljubljana: Mladinska knjiga, 2014. 363-366.

Smith, Sidonie and Julia Watson. Reading Autobiography. A Guide for Interpreting Live Narratives. Second edition. Minneapolis, London: University of Minnesota Press, 2010.

Villaverde, Marcelino Agís. "Paul Ricoeur and Philosophy in the Twentieth Century." http:// www.fondsricoeur.fr/uploads/medias/espace_chercheurs/paul-ricoeur-and-philosophy-in-the-twentieth-century-1.pdf.

Zupan, Vitomil. Sholion. Maribor: Založba Obzorja, 1973.

Zupan, Vitomil. Igra s hudičevim repom. Murska Sobota: Pomurska založba, 1978.

Zupan, Vitomil. Komedija človeškega tkiva. I-II. Ljubljana: Cankarjeva založba, 1980.

Zupan, Vitomil. Menuet za kitaro (na petindvajset strelov). Murska Sobota: Pomurska založba, 1980.

Zupan, Vitomil. Levitan. Roman ali pa tudi ne. Zagreb: Globus and Murska Sobota: Pomurska založba, 1985.

Zupan, Vitomil. Apokalipsa vsakdanjosti. Ljubljana: Mladinska knjiga, 1988.

Zupan Sosič, Alojzija. "Pregibanje okrog telesa (o erotiki v romanih Vitomila Zupana)". Slavistična revija 52.2 (2004): 157-180.

\section{ABOUT THE AUTHOR}

Andreas (Andrej) Leben is a professor at the Department of Slavonic Studies at University of Graz. His research interests focus on modern Slovene literature, autobiographical discourse and autobiographical writing, polysystems and cultural transfer, memory culture and the literature of the Slovene minority in Austria. He is head of a FWF-project about the bilingual literary practice in Carinthia and its position in the supra-regional sphere of interaction (https://slawistik. uni-graz.at/en/bilinguale-literarische-praxis/). Together with Alenka Koron he is editor of the volume Avtobiografski diskurz (Ljubljana 2011), a collective monograph on the theory and practice of autobiography in literary studies, the humanities and social sciences. Some recent articles: From Bakhtin to Kovačič: From the Ethics to the Aesthetics of Life in Autobiographical Writing (Slovene Studies 36.2); Gendered Perspectives on Sexuality, Body and Aging in Slovene Autobiographical Literature: Mrak-Zupan-Kovačič in: Aging in Slavic Literatures: Essays in Literary Gerontology, ed. by Dagmar Gramshammer-Hohl (Bielefeld 2017).

\section{NOTES}

1 Paul John Eakin, 'Introduction: Mapping the ethics of live writing,' in Paul John Eakin ed. The ethics of life writing. Ithaca, London: Cornell University Press, 2004 (pp. 1-16; p. 1, p. 5). 
2 Idem (p. 8).

3 Idem (p. 15).

4 The article was first published in Mikhail M. Bakhtin. Estetika slovesnogo tvorchestva. Ed. Sergei G. Bocharov. Moscow: Iskusstvo, 1979.

5 See also his article Art and answerability (Iskusstvo i otvetstvennost) from 1919 where Bakhtin argued that the individual can unify science, art and life in an entity if he assumes complete answerability in art as well as in life. Michael Holquist and Vadim Liapunov ed. Art and answerability. Early philosophical essays of M. M. Bakhtin. Trans. Vadim Liapunov. Austin: University of Texas Press, 1990 (pp. 1-3).

6 Mikhail M. Bakhtin, 'Author and hero in aesthetic activity,' in Michael Holquist and Vadim Liapunov ed. Art and answerability. Early philosophical essays of M. M. Bakhtin. Trans. Vadim Liapunov. Austin: University of Texas Press, 1990 (pp. 7-180; p. 15, 17).

7 Idem (p. 22).

8 Idem (p. 205).

9 Idem (p. 206).

10 Idem (p. 12, p. 14).

11 Greg Mark Nielsen, The norms of answerability. Social theory between Bakhtin and Habermas. Albany: State University of New York Press, 2002 (p. 92).

12 Sidonie Smith and Julia Watson, Reading autobiography. A guide for interpreting live narratives. Second edition. Minneapolis, London: University of Minnesota Press, 2010 (pp. 79-81).

13 See Marcelino Agís Villaverde, 'Paul Ricoeur and philosophy in the twentieth century.' http://www.fondsricoeur.fr/uploads/medias/espace_chercheurs/paul-ricoeur-andphilosophy-in-the-twentieth-century-1.pdf.

14 Paul Ricoeur, Das Selbst als ein Anderer. München: Fink, 1996 (pp. 210-211, pp. 247-248).

15 See e. g. Smith and Watson 2010 (pp. 218-222).

16 Idem (p. 241).

17 James Phelan, 'Narrative ethics.' http://www.lhn.uni-hamburg.de/article/narrativeethics.

18 Vitomil Zupan, Levitan. Roman ali pa tudi ne. Zagreb: Globus and Murska Sobota: Pomurska založba, 1985 (p. 59).

19 Vitomil Zupan, Sholion. Maribor: Založba Obzorja, 1973 (p. 63).

20 Vitomil Zupan, fasc. 10, map 75, Archive of the National and University Library in Ljubljana.

21 Vitomil Zupan, Menuet za kitaro (na petindvajset strelov). Murska Sobota: Pomurska založba, 1980 (p. [9-11]).

22 Ifigenija Simonović ed., Vitomil Zupan. Važno je priti na grič. Življenje in delo Vitomila Zupana (1914-1987). Ljubljana: Mladinska knjiga (p. 94).

23 Vitomil Zupan, Komedija človeškega tkiva. Prva knjiga. Ljubljana: Cankarjeva založba, 1980 (pp.10-11).

24 Vitomil Zupan, Komedija človeškega tkiva. Druga knjiga. Ljubljana: Cankarjeva založba, 1980 (pp. 119-120).

25 Alojzija Zupan Sosič, 'Pregibanje okrog telesa (o erotiki v romanih Vitomila Zupana),' in: Slavistična revija 52.2, 2004 (pp. 157-180; p. 158).

26 Lojze Kovačič, Zrele reči. Ljubljana: Študentska založba, 2009 (p. 80).

27 See Andrej Leben, 'O "Zrelih rečeh" in drugih stvareh Lojzeta Kovačič.' In: Alojzija Zupan Sosič ed. Sodobna slovenska književnost (1980-2010). Ljubljana: Znanstvena založba Filozofske fakultete, 2010 (pp. 157-163).

28 Lojze Kovačič, Delavnica. Šola pisanja. Maribor: Založba Obzorja, 1997 (p. 187).

29 With regard to similarities and differences in Bakhtin's and Kovačič's aethetical concepts see Andreas Leben, 'From Bakhtin to Kovačič: From the Ethics to the Aesthetics of Life in Autobiographical Writing.' Slovene Studies 36.2, 2014 (pp. 83-95). 
30 Kovačič, Delavnica (p. 27, p. 187).

31 Kovačič, Zrele reči (pp. 147-148, p. 236).

32 Idem (p. 80).

33 Idem (p. 60, p. 147).

34 Aleš Berger ed., Vitomil Zupan. Ljubljana: Nova revija, 1993 (pp. 213-214).

35 Lojze Kovačič, Sporočila iz sna in budnosti. Opuskule. Ljubljana: Mladinska knjiga, 1987 (pp. 237-245).

36 It should be noted that Zupan wrote in prison among other things an essay where he distinguished between the ethics as a theoretical science which is based on epistemology and morality as a normative and practical science. As the subjects of ethics are the "good" and the "negative good" and the subjects of logic correct and incorrect thinking, he saw ethics as a form of instinctive logic (nagonska logika) and logic as philosophical ethics (mišljenska logika). See Vitomil Zupan, fasc. 12, map 92, Archive of the National and University Library in Ljubljana, Slovenia.

37 Kovačič, Zrele reči (p. 173).

38 With regard to The Newcomers see Marjan Dolgan, 'Véliki tekst o demistifikaciji „Velikega teksta“ ali Prišleki Lojzeta Kovačiča,' in: Marjan Dolgan. Slovenska knjižeunost tako ali drugače. Ljubljana: Slovenska matica, 2004 (pp. 141-165, p. 162).

39 Zupan, Komedija človeškega tkiva II (pp. 26-27).

40 Vitomil Zupan, Apokalipsa vsakdanjosti. Ljubljana: Mladinska knjiga, 1988 (pp. 178-179).

41 Kovačič, Zrele reči (pp. 263-264, p. 282).

42 Lojze Kovačič, Kristalni čas. Ljubljana: DZS, 1990 (p. 319).

43 Lojze Kovačic, Vzemljohod. Ljubljana: Slovenska matica, 1993 (p. 205, pp. 208-209).

44 Lojze Kovačič, Tri ljubezni. Ljubljana: Sanje, 2004 (p. 306).

45 Zupan, Komedija cloveškega tkiva II (pp. 11).

46 Zupan, Apokalipsa vsakdanjosti (pp. 208-210).

47 Idem (pp. 218).

48 Janko Kos, 'Zločin in kazen Vitomila Zupana,' in: Aleš Berger ed. Vitomil Zupan. Ljubljana: Nova revija, 1993 (pp. 7-20, p. 19).

49 Miljenko Jergović, 'Čeble in ljudje,' in Ifigenija Simonović ed. Vitomil Zupan. Važno je priti na grič. Življenje in delo Vitomila Zupana (1914-1987). Ljubljana: Mladinska knjiga (pp. 363-366, p. 363).

50 France Pibernik, Čas romana. Pogovori s slovenskimi pisatelji. Ljubljana: Cankarjeva založba 1983 (p. 101).

51 Kovačič, Zrele reči (p. 246).

52 Vitomil Zupan, fasc. 10, map 75, Archive of the National and University Library in Ljubljana.

53 Vitomil Zupan, Igra s hudičevim repom. Murska Sobota: Pomurska založba, 1978 (p. 7).

54 Kovačič, Delavnica (p. 187).

55 Lojze Kovačič, Prah. Dnevnik, zapažanja, reminiscence. Ljubljana: Mladinska knjiga, 1988 (p. 212).

56 Kovačič, Zrele rě̌i (p. 259).

57 Idem (p.216).

58 Idem (p. 399).

59 Idem (p. 81). 